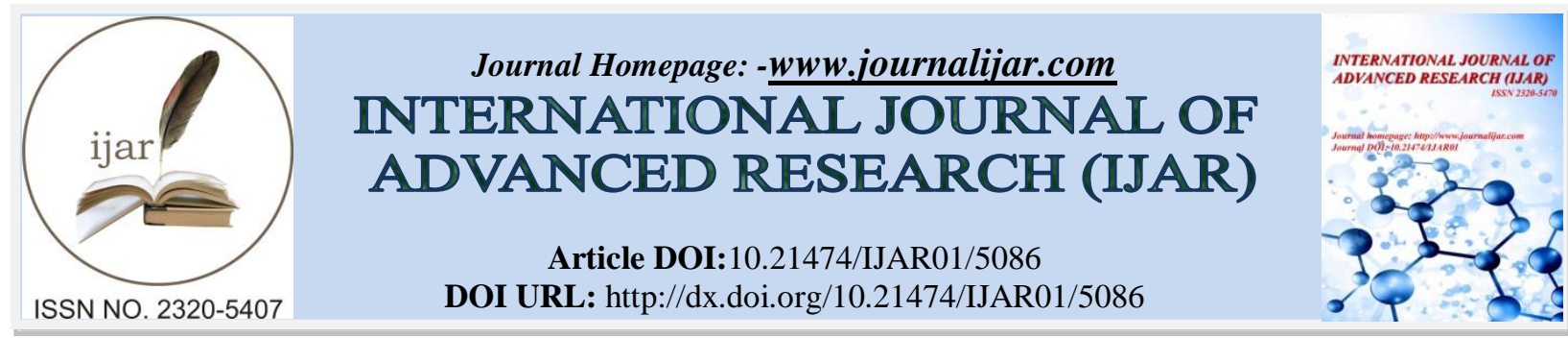

RESEARCH ARTICLE

\title{
LEADERSHIP QUALITIES ON CRISIS MANAGEMENT STRATEGY IN AL AIN CIVIL DEFENSE CENTER, AL AIN, ABU DHABI.
}

\begin{abstract}
Ayman Alarmoti.
Assistant Professor of Business Administration.

\section{Manuscript Info}

Manuscript History

Received: 06 June 2017

Final Accepted: 08 July 2017

Published: August 2017

Abstract

This study tried to identify the impact of leaders in Al Ain General Directorate of Civil Defense to face differing crises by identifying the extent of these leaders to deal with crisis management strategies and its sequenced stages by possessing different leadership qualities. Descriptive analytical approach was adopted beside the field study using a questionnaire prepared for achieving objectives of the study. Population of the study included directors and general directors in the directorate with a total 80 directors. Sample of the study included 45 director who were chosen randomly and received only 40 questionnaires due to difficulty of collecting the total number of the research community which is equivalent to $65 \%$ of the total number of directors. Data were analyzed using simple and multiple regression, and statistical correlation coefficient to test research hypotheses.

Results of this research illustrated that leaders in the directorate have the capacity and qualities that enable them to manage any potential crisis during its different stages.
\end{abstract}

Copy Right, IJAR, 2017,. All rights reserved.

\section{Introduction:-}

Current world is characterized with steady changes; technologically, socially, politically, and economically which added difficulty and complexity on tasks of leadership in various organizations due to accompanied changes in both organization or community. Organizational and business strategies must keep pace with new technology; organizational structures must be consistent with all strategies and regulatory environment, and with the technological changes on another hand(Norman, 1995).

These accelerated changes caused various types of crises in service organizations which make crises normal part of organization's life. There's no organization far from crisis that threatening its survival; which in turn gives great importance to have a clear strategy for crisis management with the need to leaders who enjoy professional leadership qualities that qualify them to manage different crisis which gives special importance of leadership qualities in managing crisis (Norman, 1995).

Thus, this research seeks to clarify relationship between leadership qualities of leaders and their ability to manage crisis as well as impact of these qualities in stages of crisis management. Al Ain General Directorate of Civil Defense has been selected to be examined due to its major role in providing the civil defense services in $\mathrm{Al}$ Ain.

Corresponding Author:- Ayman Alarmoti.

Address:-. Khawarizmi International College / United Arab Emirate / Al Ain 


\section{Selecting a problem and problem statement:-}

Crises are critical phenomena in the life of any organization, there's no organization -regardless of its size or naturefar from crises because if the organization isn't in a crisis now, it's at some point before the crisis and need to be prepared to face such crisis. Crises don't threaten continued operations of the organization only, but it threatening its life and survival. So, organization must to have conscious leaders with personal attributes able to adopt useful strategies to protect the organization before, during and after crisis(Mitroff, 1993).

This research deals with qualities of the administrative leadership and its actions during crisis management within Al Ain General Directorate of Civil Defense. Descriptive analytical approach was adopted to deal with phenomena and practices available for study and measurement as they're without the intervention of researcher.

\section{Problem : Definition, Statement:-}

Easiest way to define research problem is by converting research title into the main statement/question of the study as follows; "What's the impact of leadership qualities on crisis management strategy in Al Ain Civil Defense Center? From this core question; another sub-questions appeared as follows;

1. Does General Directorate of Civil Defense in Al Ain possess administrative leaders who have enough leadership characteristics that qualify them to pursue a professional strategy to manage crisis?

2. What're the methods used by General Directorate of Civil Defense in Al Ain in managing crisis?

3. Can General Directorate of Civil Defense in Al Ain predict occurrence of crises before happing?

\section{Purpose/Objective of the research study:-}

Researcher's objective in the first place is to contribute with the results of the study in identifying impact of leaders in the Directorate to face crises and discovering the most important strengths and weaknesses that contribute in facing crises through recommendations of the researcher that he hopes it will be taken into consideration as a strategy in facing crises in addition to construct other prospective studies covering aspects not covered by this research. Other sub-objectives of the study can be summarized as;

1. Identifying availability of leadership qualities in leaders of General Directorate of Civil Defense in Al Ain.

2. Recognizing reality of methods followed by General Directorate of Civil Defense in Al Ain in dealing with its crises.

3. Identifying impact of leadership qualities of leaders in General Directorate of Civil Defense in Al Ain in dealing with crisis.

\section{Study significant:-}

Significant of the study comes from what facing the organizations of multiple crises which requires creating effective management system to avoid these crises. Importance of the study is enhanced through the nature of the work of the General Directorate of Civil Defense in Al Ain in providing fair civil defense service within Al Ain City and its suburbs which have become the backbone of the safe life in that area which requires to find professional solutions and strategies for more effective management of crises in the long run.

\section{Constructing study hypothesis:-}

The researcher's depended on a central core hypothesis with variety of aspects, as; there're statistical significant differences between the leadership qualities with its five aspects - higher sense of responsibility, ability to act in critical situations, high degree of intelligence, restraint and emotional maturity, flexibility and imagination -, and between the stages of crisis management with its five aspects - discovery of early warning signals, preparedness and prevention, containing damages, restoring activity, learning -.

\section{Identifying and labeling variables:-}

1. The independent variable represented in the leadership and administrative qualities of the leader - higher sense of responsibility, ability to act in critical situations, high degree of intelligence, restraint and emotional maturity, flexibility and imagination - who is capable of adopting strategies that lead to success of the organization through his vulnerability to lead others successfully and having a clear strategic vision with the other qualities of;

2. The dependent variable represented in the stages of crisis management - discovery of early warning signals, preparedness and prevention, containing damages, restoring activity, learning - that represent the main tasks adopted by the organization in crisis management. Failure of decision-maker to handle and stage will be the cause of exacerbated for the crisis. 


\section{Limitations and Boundaries:-}

The researcher didn't face much limitations upon completing the study, except when he tried to distribute the questionnaire due to the work nature and emergencies which reduce the opportunity to meet respondents and discuss questionnaire's statements with them. The study included the following boundaries;

0 . Time boundary; September and October of 2015.

1. Spatial boundary; General Directorate of Civil Defense in Al Ain.

2. Human boundary; Managers and leaders working in the directorate.

3. Objective boundary; studying impact of leadership qualities on crises management.

\section{Arrangement and Approach of study:-}

Both theoretical and practical research tools were used during the research such as references and previous studies that employed in construction theoretical framework of the study. The practical side was applied by the field visits and conducting personal interviews and field observations. The main tool in this aspect was questionnaire to collect the basic data for measuring variables of the study.

\section{Methodology of research:-}

This research discussed the topic of administrative leadership upon managing crisis. The researcher used the descriptive analytical method because it's a way to handle the available practices of the topic and measuring it as it's without the intervention of the researcher.

Research tools in its theoretical and practical sides were represented into references which were employed in construction of theoretical framework from books, students, researches, articles, academic papers, and Internet. The practical side was done as the researcher relied on field visits and conducting field views. The main tool in this study is a questionnaire (attached into appendixes) which was adopted by the researcher in the basic data collection. This questionnaire aimed to measure variables of crisis management in addition to measuring characteristics variables of leadership where the researcher adapted some of the questions used on administrative leaders attributes.

\section{Corporate Description:-}

\section{Organization's activities:-}

Massive care and attention given by His Highness Sheikh Khalifa bin Zayed Al Nahyan "President of the UAE, the Emir of Abu Dhabi and the commander of the Union Defence Force" and His Highness Lieutenant General Sheikh Saif bin Zayed Al Nahyan "Deputy Prime Minister and Minister of the Interior" to the sector of civil defense contributed in illustrating the importance of proper planning based on facts and the integration of strategic management with the change management in a new view to the development of civil defense sector in the emirate (Khaleej Times and Civil Defence Media Office, 2015).

Abu Dhabi Civil Defense Sector has started to make confident effort to lay the foundations of stability for the emirate of Abu Dhabi and meets aspirations of the citizens with the expansion in the establishment of modern centers to cover all residential, commercial, and industrial areas bringing the number of centers in the emirate to 52 advanced centers equipped with the most qualified Human cadres and equipments needed to cope with all types of incidents and under all circumstances in addition to meet ambition and hopes of the wise leadership(Khaleej Times and Civil Defence Media Office, 2015).

Main responsibilities of Al Ain Civil Defense Center is to protect the valuable material and human resources in addition to protecting private and public properties. In addition to the former protection activity; the wise leadership adopted a set of preventive measures and laws that ensure the safety of buildings and constructions to reduce potential life and property losses and provide a safe environment that promotes stability and investment in order to avoid any potential problems or disasters in the future which ensure to provide effective civil protection services on both sides of treatment and prevention (Khaleej Times and Civil Defence Media Office, 2015).

Strategic Management (Abu Dhabi Civil Defense General Directorate , 2014)

- Vision: working effectively for making the United Arab Emirates the most secure country in the world.

- Mission: committing to provide the finest civil protection methods through the full application of the highest standards of prevention and rescuing in addition to excellence in implementing the fire and rescue operations.

\section{- Objectives:}

$\circ$ Establish superiority and corporate excellence. 
- Presenting preventive safety in all sites and locations.

○ Dissemination of preventive safety and community awareness culture.

- Developing human resources in the civil defense skills.

- Developing the human resources excellence in fire, rescue, and first aid skills by applying the latest practices and provide better initiatives.

- Coordination and mutual support between teams and outstanding field performance in the face of major accidents, crises and disasters.

\section{- Top Leadership's role}

○ Preparing the annual plan for the center and forming the foundations and rules of work beside following up its implementations.

- Participation in preparation of estimated annual budget to center's needs and work on provide such needs.

- Supervising the preparation of civil defense strategy in the city of Al Ain accordance with the strategy of the General Headquarter.

- Preparing a comprehensive plane to face disasters, accidents, and fires in $\mathrm{Al}$ Ain and provide the requirements of suitable implementation.

- Following up specialist fire fighting activities and provide required specialized cadres, supplies, and mechanisms.

- Supervise the preparation and implementation of civil protection plan on civil, industrial, and residential locations.

- Enhance communication and customer service for improving awareness about the field of volunteerism and raise community culture among individuals.

- Reviewing results of disasters and fires in Al Ain and prepare needed reports.

\section{- Business and functional strategies}

- Consolidation of organizational excellence in fire and rescue and first aid by applying the latest practices and provide better initiatives.

- Coordination and mutual support between the teams and the outstanding field performance in the face of major accidents, crises and disasters.

- Preventive safety insurance in all sites and locations by developing employees' skills according to professional standards to ensure presence of qualified and equipped manpower capable of dealing with various types of risks.

- Strengthening of strategic thinking and future outlook among planners and team leaders in charge of projects and the individuals involved in the implementation of the field, preventive and awareness-raising and administrative duties.

- Administrative and structural development in all stages and different functional mattresses to ensure the clarity of goals and objectives and the effectiveness of the right projects and the accuracy of the procedures and results excellence.

\section{Current Projects undertaking:-}

Al Ain Civil Defense Center as a part of Abu Dhabi Civil Directorate is adopting a comprehensive new project on safety it is; "Train the Trainers" which will provide enough amount of training for the education professionals in the areas of Al Ain City about the safety issues and the latest preventive activities because the educational organizations become a vital partners in protection activities against risks whether by providing safety precautions at educational buildings or spreading awareness about safety and preserving safety among students in the schools. Abu Dhabi Civil Directorate is planning to expand that project to the whole UAE because it accomplished extraordinary accomplishment in Al Ain City due to the nature of the project as a sustainable project(Ministry of Interior, 2014).

\section{Industry Analysis:-}

Discussion of the position of the Al Ain Civil Defense Center with related to its business activities within the civil defense services will benefit the center at first then it can be adopter to the different centers of the UAE especially within the context of globalization. Conducting an environmental scanning for the outer and inner environment for the center is a useful tool to compare opportunities and threats with strengths and weaknesses which in turn will enable analyzing the overall situation of the organization. The following table will show the most important elements of the environmental scanning of the organization. 


\section{Internal Environment (Strengths and Weaknesses)}

\section{1) Administrative Factors}

15. Social Responsibility.

16. Dealing with inflation.

17. Rapid information exchange.

18. Dynamic of the organization.

19. Strategic Planning and Analysis.

20. Flexible organizational structure.

21. Considering environmental factors.

22. Forecasting environmental factors.

23. Retain talents with creative capacity.

24. Efficiency of communication system.

25. Adapt advanced technological changes.

26. Perseverance and ability to deal with crises.

27. Rapid responding to different circumstances.

28. Flexibility in different environmental variables.

\section{2) Financial factors}

37. Uses of capital.

38. Average costs.

39. Sources of capital.

40. Degree of liquidity.

41. Return on investment.

42. Easily out of the market.

43. Degree of financial stability.

44. Ability to repay short-term obligations.

45. Ability to repay long-term commitments.

46. Ability to expand to meet growing demand.

47. Ability to use a weapon of competitive quality.

\section{3) Human factors:}

\section{Possibilities.}

60. Qualification level.

61. Capacity and trends.

62. Rehabilitation possibilities.

63. Motivation and enthusiasm.

64. Administrative experience and qualification.

\section{4) Technological factors}
69. Economies of scale.
70. Applied technology.
71. The use of resources
72. Performance efficiency.

\section{External Environment (Opportunities and Threats)}

1) Political and Legal Factors

4. Stakeholders.

5. Special incentives.

6. Employment laws.

7. Ruling regime trends.

8. Historical circumstance.

9. Civil Defense Regulations.

10. Stability of the government.

11. Foreign Trade Regulations.

12. Trend towards foreign partnerships.

13. State relationship with outside world.

14. Environmental protection Regulations.

\section{2) Economic Factors}

29. Interest rates.

30. Chain suppliers.

31. Alternative services.

32. Unemployment rates.

33. Trends in gross national product.

34. Control of wages and prices and fees.

35. Level of per capita income and competition.

36. Stability of currency value, availability and cost of energy.

\section{3) Social, cultural, and educational factors}

48. Birth rates.

49. Value systems.

50. Life expectancy.

51. Cultural legacies.

52. Change in lifestyle.

53. Population growth.

54. Consumers activity.

55. Professional orientation.

56. Regional shift in population.

57. Educational and cultural levels.

58. Population concentration areas.

\section{4) Technological factors}

65. Concentration of technological efforts.

66. Total government spending on research and development.

67. Total education spending on research and 
73. Added value of the service.

74. Technical and technological skills.

75. Effectiveness of training programs.

76. Level of technology used in services.

77. Ability to evaluate innovations into processes.

78. Ability to transfer ideas to a field of application. development.

68. Improve productivity and efficiency through automation.

\section{Organizational Analysis:-}

The following points will present real facts the work nature of Al Ain Civil Defense Center regarding different majors as the following;

\section{Management related organizational analysis:-}

Al Ain Civil Defense Center has been located into a central location that achieves perfect coverage for emergency response vehicles with good access to main streets to create smooth preventive activities. Internal customer attend to the center to benefit from civil defense services presented by the administrative sector of the center to have services including and not limited to the following; buildings completion certificate, gas systems completion certificate, approval of building drawings for fire prevention systems, initial drawings approval for buildings and establishments, approval of additions or modifications in drawings for buildings and establishments, adoption of trading companies to import and export hazardous materials, cancelling or adoption or renewing or modifying of licenses for factories and trading companies for hazardous materials, license approval for storing hazardous materials, cancelling or renewing or modifying license for storing hazardous materials, licensing or cancelling or renewing or modifying tanks transporting hazardous materials, approval of decoration drawings, licensing or cancelling or renewing license vehicles transporting gas cylinders, etc.... (UAE Ministry of Iinterior, 2015) External costumes is the customer who benefit from the services of the center outside its location in case of fire or accident. Both of internal and external receive the same amount of interest and care from the center.

Leadership of the center is trying to check its services' quality continuously which has a clear impact on the wider organizational process as it brings the entire center to a professional change upon addressing emergencies and crises in order to achieve and maintain a competitive advantage. The services of Civil Defense has set into six key risks, as; storms, winds, earthquakes, hurricanes, fires, and floods. Thus, Al Ain Civil Defense center is working on developing plans to reduce losses in lives and property through a general and comprehensive risk management plan and in cooperation and coordination with various agencies. The plan focuses on three main topics: training, evacuation and sheltering, and media which in turn achieve and maintain the competitive advantage for the center. As a result of that Al Ain Civil Defence Center became a leading agency in this comprehensive plan(National Emergency, Crisis and Disaster Management Authority, April).

\section{HR related organizational analysis:-}

The major findings appeared from the performance appraisals showed that Al Ain Civil Defense is working at providing equipment and machinery in preparation for rescue operations as it recognized the importance of the exchange of experience and performance management by providing the equipment at any time, and developing strategic plans to address crises, and risk assessment plans. Also, Al Ain Civil Defense Center highlighted the need to qualify individuals on dealing with risks through training courses and workshops(Abu Dhabi Civil Defense Genral Directorate, 2015).

Al Ain Civil Defense Center has its different technique to help in staff retention since it has chosen to train its staff by the top three international schools; Canadian, British and Singaporean; each of which deploys its own teaching method. Al Ain Center has trainees from three different schools whose ideas intersect and develop to produce customized Emirati methods and ideas. The lowest-ranking of these officers works as a consultant at the Civil Defense. Also, Al Ain Center is keen on the safety of its personnel, particularly its firemen, hence their costly uniforms. Each member of the staff wear the best, safest and most expensive uniforms -each costs us AED 11,000. Their clothing tolerates temperatures as high as 150 degrees; same applies for their helmets and gloves. To guarantee quality and avoid any scams, Al Ain Center got an ambulant laboratory which tests the uniform's 
specifications and temperature tolerance prior to purchasing them (His Excellency Major General Expert Rashid Thani Al Matrooshi, 2014)

\section{Accounting related organizational analysis:-}

There are different accounting techniques used by Al Ain Civil Defense Center to help the managerial decisions including; performing financial analyzes which used to prepare the budget for implementation of programs and performance style, unify the accounting basis used in the preparation of all sections of the general budget and its implementation in accordance with the cash basis including processes related to the purchase of non-financial assets, and provide a conceptual framework and a comprehensive accounting is appropriate for the analysis and assessment of fiscal policy, which often provide non-market services primarily (Khaleej Times and Civil Defence Media Office, 2015).

Al Ain Civil Defense Center is using the computerized accounting information system for the prevention of fraud and erroneous transactions. In order to take advantage of its effects on efficiency and productivity, where these systems have become a necessity in the current era after the creation of global progress in the field of accounting information systems, new patterns of work as a result of developments and transformations taking place in the world. Audit firms currently facing in light of the enormous development in information technology and how to use it or its development and produced positive effects on audit firms (National Emergency, Crisis and Disaster Management Authority, April).

\section{Marketing related org analysis:-}

Activities of $\mathrm{Al}$ Ain Civil Defense Center in media advertising direct marketing, sales promotion, publicity/public relations, and personal selling in the total communications process can be mentioned into some of the following(Khaleej Times and Civil Defence Media Office, 2015);

- Prepare a media plan to publicize the activities of civil defense, which carried out by the center and its achievements and its role in promoting the security situation and community safety.

- Prepare and review of media interviews and statements with the Department of Public Relations and Media at the Ministry of the Interior to obtain such approvals make statements and conduct meetings.

- Prepare the periodic report of the Information and Public Relations Center, containing the evaluation of media performance and the achievement of its objectives and to provide remedial proposals.

- Media coverage of all the events and activities of the center in cooperation with the competent authorities in the ministry.

- Preparing fires and accidents prevention publications on a regular basis to provide information of interest to the leadership and their formations and their audience and to facilitate the deal among themselves.

- Guests and visiting delegations and securing their movement and residence in coordination with the competent authorities and institutions receiver.

- Supervision of the officers and employees of the General Command of Civil Defense and formations, coordinating and organizing social, cultural and recreational activities for them and their families Club.

Al Ain Civil Defense Center is adopting carious methods and E-marketing strategy including dome of the following (Civil Defense Genral Command , 2015);

- Preparing to participate in the Arab and international conferences, seminars and follow-up plan implemented in coordination with the competent authorities.

- Coordination of efforts in the preparation and organization of meetings and conferences of the leaders of the civil defense of the Gulf Cooperation Council in coordination with the competent authorities of the Ministry of Interior.

- The translation of documents and research provided for conferences and seminars and correspondence for civil defense.

- Study the resolutions and recommendations of the competent work of civil defense and international conferences, as well as international organizations, civil protection coordination with the competent authorities.

- The application of modern management systems in the completion of management tasks, seeking to keep pace with advanced technologies and software, and a commitment to quality and excellence standards.

- Preparation of periodic reports and the exceptional performance of the Department for the adoption of institutional performance and identify problems and propose alternatives and solutions development with measurable criteria. 


\section{Data Analysis :-}

This phase will discuss the characteristics of study sample and the population of the study in addition to presenting an analysis for the data collected from the sample as follows;

\section{Survey Sampling:-}

This study tried to answer the main problem statement of "What's the impact of leadership qualities on crisis management strategy in Al Ain Civil Defense Center? Thus, population of the study included all the working staff of Al Ain Civil Defense Center with all its military, civil, technical, and service levels including directors and general directors with a total 80 directors. Sample of the study included 45 director who were chosen randomly and received the form of the questioner to answer its statements. There were only 40 questionnaires restored from the 45 form distributed on the sample due to difficulty of collecting the total number of the research community which is equivalent to $88 \%$ of the total number of the sample. Data were analyzed using simple and multiple regression, and statistical correlation coefficient to test research hypotheses.

Distribution of the questionnaires

$\begin{array}{llll}\text { Distributed } & \text { Restored } & \text { Expelled } & \text { Final } \\ 45 & 40 & 5 & 40 \\ 100 \% & 88 \% & 12 \% & 88 \%\end{array}$

Qualitative and quantitative data:-

Qualitative research depends on studying and reading data in a non-quantitative method where data isn't converted to numbers. Results can be obtained from observing and analyzing events, attitudes, photos, documents and verbal and non-verbal communication. Quantitative research depends on reasons and facts from perspective of relationships between variables and so can be explained by cause and effect relationships between these variables. It becomes possible to achieve accurate predictions about the phenomenon or phenomena under study (Rumi, 2015).

Quantitative data was used during the study as is aims at testing the experimental variables by controlling or adjusting the interceptor variables that appear in the context of the study. Through that the relationships between variables can be generalized as similar predictable in communities. Questionnaire depended on a number of statements to measure the stages of crisis management variables. Also, researcher adapted some of the statements to measure leadership characteristics variables on administrative leaders attributes.

The survey plan and choice of data collection method was a form of questionnaire adopted by the researcher and attached into appendix to collect the basic data which tried mainly to measure correlation and the extent of relationship between the different variables of leadership qualities and crises management stages to see if the change of one or a combination of them linked to the other change of not. Correlation analysis means the study of the relationship between two variables, the main objective is to determine the extent of his degree of relationship between variables from the no correlation to complete the correlation.

Tables, Charts, and Pareto Analysis

\begin{tabular}{|c|c|c|c|c|c|}
\hline $\begin{array}{cc}\text { Crisis } & \begin{array}{c}\text { Management } \\
\text { Stages }\end{array} \\
\text { Leadership } & \end{array}$ & $\begin{array}{l}\text { Discovering } \\
\text { early warning } \\
\text { signals }\end{array}$ & $\begin{array}{l}\text { Preparedness } \\
\text { and } \\
\text { prevention }\end{array}$ & $\begin{array}{l}\text { Damage } \\
\text { containing }\end{array}$ & $\begin{array}{l}\text { Restore } \\
\text { activity }\end{array}$ & Learning \\
\hline & Correlation & Correlation & Correlation & Correlation & Correlation \\
\hline High responsibility feeling & 0.033 & -0.24 & 0.370 & -0.575 & 0.181 \\
\hline $\begin{array}{l}\text { Ability to act in critical } \\
\text { situations }\end{array}$ & 0.165 & 0.301 & 0.006 & -0.262 & 0.106 \\
\hline
\end{tabular}




$\begin{array}{llllll}\text { High degree of intelligence } & -0.030 & 0.137 & 0.230 & 0.067 & -0.135 \\ \begin{array}{l}\text { Restraint and emotional } \\ \text { maturity }\end{array} & -0.066 & 0.144 & -0.309 & -0.097 & 0.193 \\ \text { Flexibility and imagination } & -0.328 & -0.023 & -0.045 & 0.124 & 0.088\end{array}$

- High responsibility feeling variable has correlation relationship with damage containing variable with 0.390 correlation; it didn't achieve any correlation relationships with other variables.

- Ability to act in critical situations variable has correlation relationship with preparedness and prevention variable with 0.301 correlation, it has correlation of 0.262 with restore activity variable; it didn't achieve any correlation relationships with other variables.

- High degree of intelligence variable didn't achieve correlation with all approved variables while it has negative correlation with discovery of early warning signals and learning variables. It has weak correlation with variables of preparedness and prevention, damage containing, and activity restoring.

- Restraint and emotional maturity variable has; negative correlation with discovery of early warning signals variable with 0.66 correlation, correlation of -0.309 with contain the damage variable, negative correlation with resort activity variable with -0.097 correlation, positive weak correlation with preparedness and prevention variable and learning with 0.144 and 0.193 respectively. 


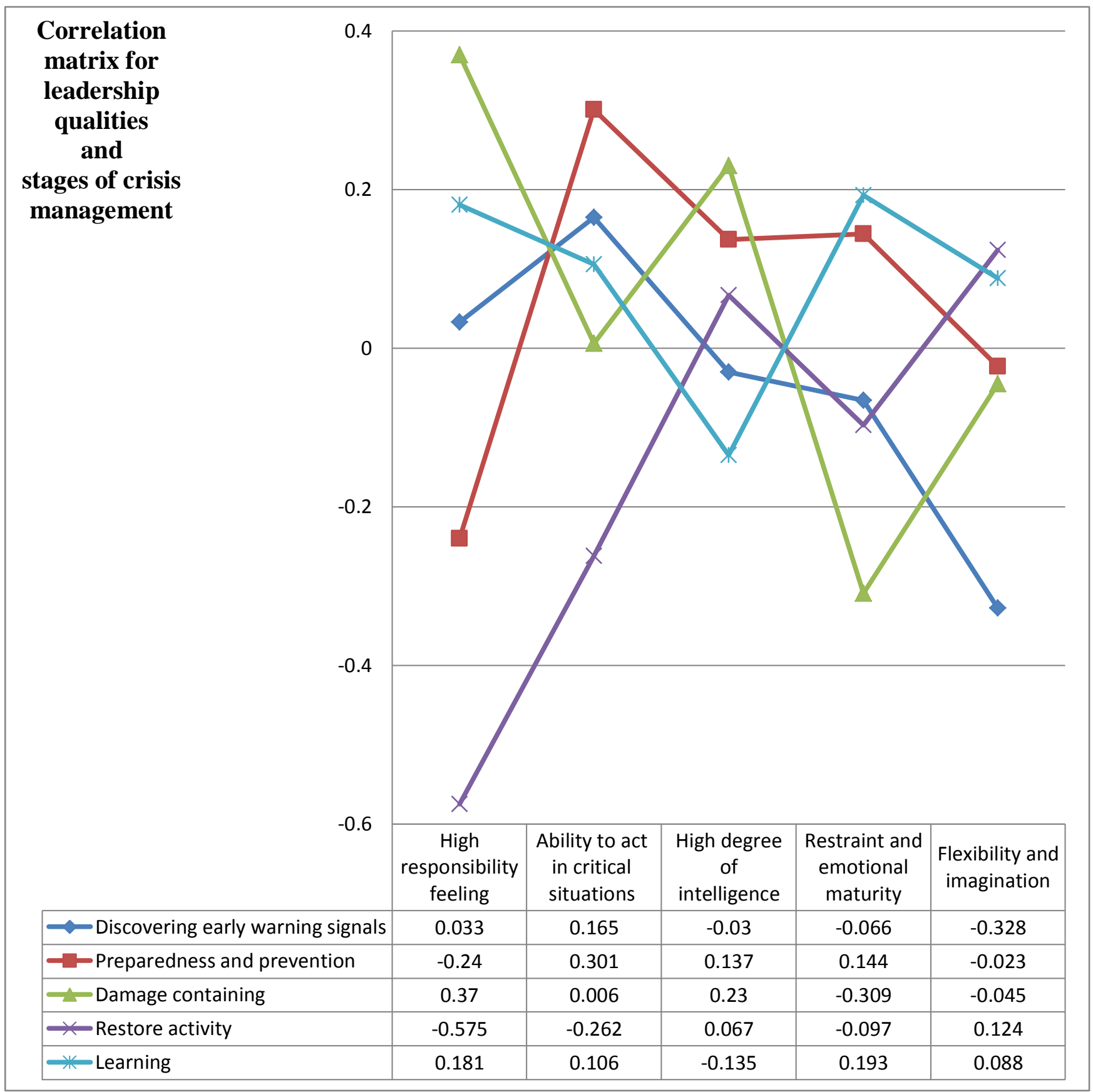

- Flexibility and imagination variable achieved negative correlation with; discovering early warning signals, preparedness and prevention, and damage correlation variables with $-0.328,-0.093,-0.045$ correlation respectively. It achieved weak positive correlation with restore activity and learning variable with $0.124,0.088$ correlation respectively.

The figure shows occurrence of the study main hypotheses about correlation relationship and statistical significant between leadership qualities of; higher sense of responsibility, ability to act in critical situations, high degree of intelligence, restraint and emotional maturity, flexibility and imagination and stages of crisis management of; discovery of early warning signals, preparedness and prevention, containing damages, restoring activity, and learning. 


\section{Research findings:-}

- Administrative leadership, which represents the research sample have a wide range of leadership qualities which are required to achieve their objectives in AL Ain Civil Deviance Center which enable them to exercise their leadership role and participate in the decision-making process which reflect on their role in facing crises positively.

- Members of the sample enjoy the latest international applied management and leadership skills which enables them to strict implementation of the various stages of crisis management which may differ in degree from one individual to another, but not non-existent start

- The conditions experienced by the United Arab Emirates locally and internationally is a period of prosperity and growth, which had a prominent impact on the behavior of many of the leaders through spreading the spirit of competition in the provision of benefit to the UAE community.

- Research sample sense of responsibility and with the leaders seek to contain the damage of the crisis with the restoration of activity and learning.

- The leaders of the research community has the ability to act in critical situations about the property phases preparedness and prevention and restoration activity guide and influence the link shown search results

- Most of the members in the sample have a common feeling they do their best in their work and adopt the leadership practices.

- The General Command of the Directorate of Civil Defense recognize the importance of professional leadership qualities and try to provide the latest training courses in order to maximize the benefits from such qualities.

\section{Contribution of this project:-}

The main problem of the study was the question of What's the impact of leadership qualities on crisis management strategy in Al Ain Civil Defense Center? The study managed to identify the impact of leadership qualities in the activities of Al Ain Civil Defense activities upon managing crises and discovering the most important strengths and weaknesses that contribute in facing crises through recommendations of the researcher that he hopes it will be taken into consideration as a strategy in facing crises in addition to construct other prospective studies covering aspects not covered by this research.

Significant of the study comes from what facing the organizations of multiple crises which requires creating effective management system to avoid these crises. Importance of the study is enhanced through the nature of the work of the General Directorate of Civil Defense in Al Ain in providing fair civil defense service within Al Ain City and its suburbs which have become the backbone of the safe life in that area which requires to find professional solutions and strategies for more effective management of crises in the long run.

\section{Limitations:-}

The researcher didn't face any external factors that impinged his ability to fully achieve the objectives because the study didn't require any external support due to the scope of the study and its internal implementation inside the center. on the other hand, the researcher didn't face much internal limitations upon completing this study due to the cooperation atmosphere of the leadership inside Al Ain Civil Defense except the time limitation about asking for some documents from the administration since it has some confidential information about the center.

\section{Recommendations:-}

Statistical analyses of the study enabled researcher to provide suggestions and recommendations that may enable $\mathrm{Al}$ Ain Civil Defense Center to provide better performance through clear strategy to avoid crisis including the following;

79. Forming a unit within the levels of organizational structure of the center with qualified staff to manage crisis and it should be linked with crisis management unit for more comprehensive crisis management process.

80. Providing crisis management unit with sufficient information about action course and its current and future requirements to enable this unit to put its strategy to prevent or monitor any potential crisis.

81. Recommendations of crisis management unit must be applied and not to be neglected which will create an inevitable exposure to crisis.

82. Giving wider powers to administrative leadership to exercise their roles because centralization may create bottlenecks and work disruptions.

83. Presenting leadership courses for leaders to form knowledge of administrative leadership, crisis management, leadership theories, social responsibility, and motivation systems. 
84. Conducting field tests for employees of the center through making crisis situation and expose them to conditions which would create a crisis to know their capabilities in discovering crisis features and how to deal with it for identifying the most skilled individuals and train the less skilled ones.

85. Dispatching highly qualified employees to developed countries to maximize their experiences from such countries, as; Britain, Japan, Germany, etc...

\section{Conclusion and lesson learned:-}

The study presented the real impact of leadership qualities on crisis management strategy in Al Ain Civil Defense Center which assured the correlation relationship and statistical significant between leadership qualities of; higher sense of responsibility, ability to act in critical situations, high degree of intelligence, restraint and emotional maturity, flexibility and imagination and stages of crisis management of; discovery of early warning signals, preparedness and prevention, containing damages, restoring activity, and learning. This result was concluded without much challenges faced by the researcher during the whole course of competing the project as he managed to present fair recommendations as a result of the study analysis.

Researcher find wide scope of support from the center except for some limitations upon asking for some documents as it takes extra time. The same support received from the academic advisor of the study. The researcher managed to adopt the academic requirements upon writing that academic paper in order put it into the right way. Most of the study phases work so well except for the part of the organizational structure because it was created on the hands of the researcher. More time limit can be done better for the research process which enable more work on collecting data about the environmental scanning for the center.

\section{REFERENCES:-}

1. Abu Dhabi Civil Defense General Directorate . (2014, October 20). Abu Dhabi Police. Retrieved October 20, 2015, from The Strategy: http://adcd.gov.ae/en/portal/the.strategy.aspx

2. Abu Dhabi Civil Defense Genral Directorate. (October, 2015). The Strategy, Retrived on 22 October, 2015 from http://adcd.gov.ae/en/portal/the.strategy.aspx

3. Civil Defense Genral Command . (2015, January 1). Functions of the Department Media Affairs. Retrieved October 22, 2015, from Ministry of Imtrtior: http://www.gdocd.gov.ae/page.php?id=8\&lang=en

4. His Excellency Major General Expert Rashid Thani Al Matrooshi, A. D.-i.-C. (2014, April 18). Our role is to safeguard lives and property. (T. w. Interviewer, Interviewer)

5. Jelaluddin Rumi 22) .October, 2015 .(Quantitative,Qualitative, and Mixed Research .San Francisco.

6. Khaleej Times and Civil Defence Media Office. (2015). Civil Defence : Disaster Reducation within sustainable development. Abu Dhabi: Khaleej Times.

7. Ministry of Interior. (2014). Safety for all. Abu Dhabi: Ministry of Interior.

8. Mitroff, P. C. (1993). From Crisis Prone to Crisis Prepared: A Framework For Crisis Management. London: Academy of Management Executive.

9. National Emergency, Crisis and Disaster Management Authority. (April, 2014 18). Nahyan bin Mubarak: successful management focuses on prevention, preparedness and building community capabilities. Taware'e wa Azamat, pp. 11-13.

10. Norman, A. (1995). Managing the Crisis you Tried to Prevent. Washington: Harvard Business Review.

11. UAE Ministry of Iinterior. (2015). Civil Defense Services and its Fees. Al Ain: UAE Ministry of Iinterior.

\section{APPENDIXES:-}

\section{A questionnaire for identifying leadership qualities on crisis management strategy in Al Ain Civil Defense Center, Al Ain, Abu Dhabi}

Dear Sir/Miss

After greetings ,,

Thank you for your time to cooperate and fill this questionnaire form aimed to identifying leadership qualities on crisis management strategy in Al Ain Civil Defense Center, Al Ain, Abu Dhabi which is a scientific exploratory survey. Your participation will have a great impact on performing the research to the required level. I hope that you may choose the suitable answer for every statement from; very agree, agree, don't know, not agree, and very not agree. All the collected data will be used for scientific purposes only. 
Personal information:-

- Age :

- Gender :

- Qualification:

- Period of experience :

- Training courses :

- Qualification :

- Specialization :

Variables statements:-

1- Personal properties for administrational leader

\begin{tabular}{|c|c|c|c|c|c|c|}
\hline & Statement & $\begin{array}{l}\text { Strongly } \\
\text { agree }\end{array}$ & $\begin{array}{l}\text { Agr } \\
\text { ee }\end{array}$ & $\begin{array}{l}\text { Neither agree } \\
\text { nor disagree }\end{array}$ & $\begin{array}{l}\text { Disag } \\
\text { ree }\end{array}$ & $\begin{array}{l}\text { Strongly } \\
\text { disagree }\end{array}$ \\
\hline 1 & $\begin{array}{l}\text { High responsibility feeling } \\
\text { - I find myself responsible for the poor } \\
\text { performance of the center. } \\
\text { - I'm effected easily with the shortage of } \\
\text { required supplies. } \\
\text { - I'm interested in forming future plans. } \\
\text { - I regret a lot upon making wrong decision. }\end{array}$ & & & & & \\
\hline 2 & $\begin{array}{l}\text { Ability to act in critical situations } \\
\text { - I feel that conditions which face the } \\
\text { organization can be handled. } \\
\text { - I have enough capacity to overcome difficult } \\
\text { situations. } \\
\text { - Difficult circumstances motivate me to find } \\
\text { many important decisions. }\end{array}$ & & & & & \\
\hline 3 & $\begin{array}{l}\text { High degree of intelligence } \\
\text { - I always give solutions for any technical } \\
\text { problems appeared at work. } \\
\text { - I've the ability to contribute in forming } \\
\text { organization's plans. } \\
\text { - I often find myself able to do new tasks to } \\
\text { serve the organization. }\end{array}$ & & & & & \\
\hline 4 & $\begin{array}{l}\text { Restraint and emotional maturity } \\
\text { - I don't care about wrong opinions and I try to } \\
\text { discuss it. } \\
\text { - I put my opinion between opinions of others } \\
\text { to be discussed. } \\
\text { - Ideas that contradict with my ideas doesn't } \\
\text { bother me }\end{array}$ & & & & & \\
\hline 5 & $\begin{array}{l}\text { Flexibility and imagination } \\
\text { - I always review and study previous plans. } \\
\text { - I always review current decisions and try to } \\
\text { re-correct it. } \\
\text { - It's useful to change programs in light of } \\
\text { emerging circumstances. }\end{array}$ & & & & & \\
\hline
\end{tabular}

\section{2- Stages of crisis management}

\begin{tabular}{|l|l|l|l|l|l|}
\hline Statement & $\begin{array}{l}\text { Strong } \\
\text { ly } \\
\text { agree }\end{array}$ & $\begin{array}{l}\text { A } \\
\text { gr } \\
\text { ee }\end{array}$ & $\begin{array}{l}\text { Neither } \\
\text { agree } \\
\text { disagree }\end{array}$ & $\begin{array}{l}\text { Dis } \\
\text { agr } \\
\text { ee }\end{array}$ & $\begin{array}{l}\text { Strongly } \\
\text { disagree }\end{array}$ \\
\hline 1 & $\begin{array}{l}\text { Discovering early warning signals } \\
\text { - The center has a unit to monitor occurrence indicators of } \\
\text { crisis. }\end{array}$ & & \\
\hline
\end{tabular}


- The center pays attention to monitoring indicators of crises.

- The center pays attention to collect and detect danger signs of the crisis.

- The center care about our training about collecting indicators of crises.

2 Preparedness and prevention

- There're different teams to solve many potential crises.

- Appropriate support is available for the team that plans and diagnoses potential crises.

- There's clear management techniques that determine procedures for dealing with imminent crisis.

- The center provides required material and capabilities for preparing and facing imminent crisis.

- There's cooperation in crisis management with government institutions and related parties

\section{Damage containing}

- The time factor is taken into account when dealing with crises to contain its damages.

- The center response to distribute tasks and powers in a suitable period when the crisis happens.

- The center uses emergency procedures that reduce and limit damages caused by the crisis.

- There's appropriate ability and speed to move the necessary resources to contain the crisis

- The center prefers to deal with crises upon happing and not before.

4 Restore activity

- The center maintains to exercise ordinary activities without delay.

- The center supports various sites which will be affected by the crisis with the needed requirements to heal its impacts and restore activity.

- The center is taking all necessary measures to mitigate effects of the crisis and limit its occurrence.

- The center works to tell the citizens and mass media about the damage caused by crisis and how to handle it.

5 Learning

- The center conjures lessons from previous crises and take advantage of it in the future

- The center assess management plans and programs of the previous crisis with a view to develop it to deal with future crises.

- The center integrate the learned lessons of the shortcomings of previous plans in future crisis plans.

- The center is working to take advantage of crisis handling methods in other centers in UAE or in other countries with similar experiences.

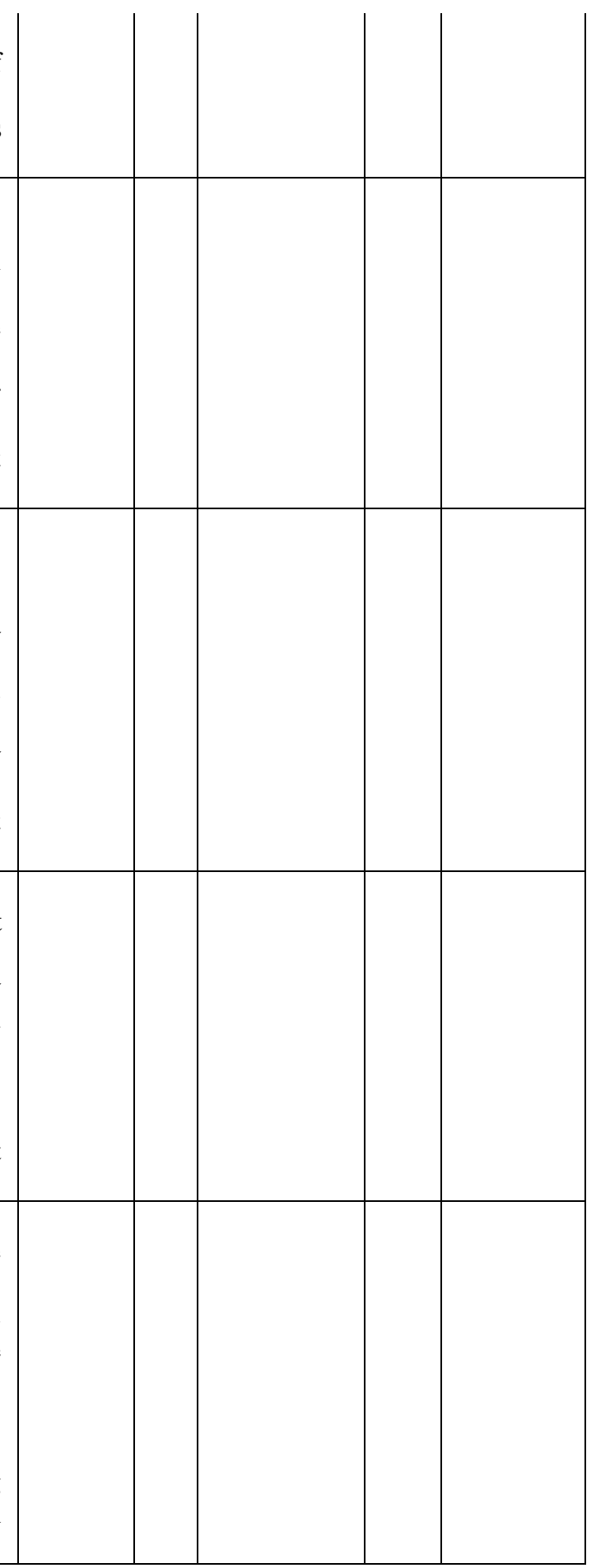

